\title{
6o. A Critical approach to the use of English in Turkey in light of linguistic imperialism
}

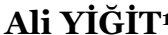

APA: Yiğit, A. (2021). A Critical approach to the use of English in Turkey in light of linguistic imperialism. RumeliDE Dil ve Edebiyat Araştırmaları Dergisi, (24), 1067-1080. DOI: 10.29000/rumelide.990739.

\begin{abstract}
Starting to attain an important international language status in the world from the $19^{\text {th }}$ century onwards thanks to many interrelated factors like British colonialism and later US-Britain cultural policies of expansion, English language has achieved an unprecedented prevalence in usage in different sectors ranging from education to tourism and art to literature and sports. Today, it keeps its reign as an international lingua franca, reinforcing its position by making use of very effective mechanisms of expansion such as globalization, academia, media, music, TV, and sports. This preponderance, or in Phillipson's words, English linguistic imperialism, however connotes oblivion and even evanescence of vernacular and the inferiorization and hybridization of national languages. As mid-20 ${ }^{\text {th }}$ century onward, Turkey's political convergence with the US has brought into the life and language of Turkish people irreversible changes whose critique, as this paper argues, can be made within the concept of linguistic imperialism. Drawing on theoretical approach by Phillipson, this paper thus discusses and critiques the ways English is used in Turkey, in an attempt to draw attention to the attrition in Turkish language, inquination in linguistic landscape, and language discrimination among the young.
\end{abstract}

Keywords: English, linguistic imperialism, attrition in Turkish language, cultural degeneration, and Turkish youth

\section{Türkiye’deki İngilizce kullanımına dil emperyalizmi ışı̆̆ında eleştirel bir yaklaşım}

$\ddot{\mathbf{O z}}$

19.yy'dan itibaren İngiliz sömürgeciliği ve ABD-Britanya kültürel yayılma politikaları gibi birbirleriyle alakalı birçok etmen sayesinde önemli bir uluslararası dil statüsü kazanan İngilizce, eğitimden turizme, sanattan edebiyata uzanan biçok farklı alanda muazzam bir kullanım sahası elde etmiştir. Günümüzde, küreselleşme, akademi, medya, müzik, TV ve spor gibi çok etkin yayılma mekanizmalarını kullanarak uluslararası geçerli dil konumunu devam ettirmektedir. Ancak, bu hakimiyet, ya da Robert Phillipson'un tabiriyle İngiliz dili emperyalizmi yerel dillerin unutulması hatta yok olması ve ulusal dillerin de ikinci dereceye düşürülmesi ve melezleşmesi anlamına gelmektedir. 20. yy. ortasından itibaren, Türkiye'nin ABD ile siyasal olarak yakınlaşması, Türk halkının hayatına ve diline geri dönüşü olmayan değişiklikler getirmiştir, ki bunun eleştirisi, bu çalışmanın iddia ettiği gibi, dil emperyalizmi kavramı çerçevesinde yapılabilir. Phillipson'un bu doğrultudaki teorik yaklaşımına dayanarak, bu çalışma, Türkiye'de İngilizce’nin kullanım şekillerini

Dr. Öğr. Üyesi, Kırklareli Üniversitesi, Batı Dilleri ve Edebiyatları, İngiliz Dili ve Edebiyatı ABD (Kırklareli, Türkiye), aliyigit@klu.edu.tr, ORCID ID: 00oo-0002-3705-4913 [Araştırma makalesi, Makale kayıt tarihi: 17.05.2021-kabul tarihi: 20.09.2021; DOI: 10.29000/rumelide.990739]

RumeliDE Dil ve Edebiyat Araşttrmaları Dergisi Osmanağa Mahallesi, Mürver Çiçeği Sokak, No:14/8 Kadıköy - ISTANBUL / TÜRKIYE 34714 e-posta: editor@rumelide.com tel: +90 $5057958124,+902167730616$

Address

RumeliDE Journal of Language and Literature Studies Osmanağa Mahallesi, Mürver Çiçeği Sokak, No:14/8

Kadıköy - ISTANBUL / TURKEY 34714

e-mail: editor@rumelide.com,

phone: +90 5057958124 , +90 2167730616 
tartışmakta ve eleştirmektedir, böylece Türkçe'deki dil aşınmasına, dilsel alandaki kirliliğe, ve gençler arasındaki dil ayrımcılığına dikkat çekmeyi amaçlamaktadır.

Anahtar kelimeler: İngilizce, dil emperyalizmi, Türkçedeki aşınma, kültürel dejenerasyon, ve Türk gençleri.

\section{Introduction}

A world bound to a single language is doomed ${ }^{2}$

(Tek dile kalmış bir dünya hapı yutmuştur)

Yaşar Kemal Gökçeli

In all parts of the world, the number of languages is dramatically decreasing in line with the decline of their speakers, replacement by dominant ones, losing their area of usages and for many other reasons. Of the nearly 6,00o living languages on earth, about 50\% is expected to die out by the end of this century (Crystal, 1997, 2012, p. 20). Mohanty (2009) emphasizes that "Nearly every fortnight, somewhere the last speaker of a language is dying. While many languages are dead or dying, a large number of languages are marginalized" (p. 4). With the death and marginalization of languages, the world is becoming linguistically and culturally more barren since it is the languages that open the door to the essence and richness of cultures, traditional values, customs and all distinctive characteristics of communities from one another. The leading English linguist, David Crystal $(1997,2012)$ reveals his concerns about the death of native languages as such:

This is indeed an intellectual and social tragedy. When a language dies, so much is lost. Language is the repository of the history of a people. It is their identity. Oral testimony provides us with a unique view of our world and a unique canon of literature. It is their legacy to the rest of humanity. Once lost, it can never be recaptured (p. 20).

While some languages are running the risk of dying or marginalization, others are becoming more and more widespread. Being known and used at varying levels by more than 1, 5 billion people across the world, English has superseded all other national languages in terms of prevalence. Recently, it has gained an unprecedented pace of usage in trade, science, international relations, media, cinematography, education, military, aviation and popular music cutting across all national boundaries. This rapid and influential spread, however, at the same time brought together socio-linguistic discussions and criticisms both at national and international levels.

There have been numerous protesting voices and acts throughout the world mobilized against unremittingly expanding English hegemony which is supported and funded under the aegis of the UK and US policies. English has been so pervasive in Europe that, it has been conceived as a threat to the linguistic and cultural diversities of the Union (Master, 1998, p. 718). Furthermore, Slovenia, France, Germany and Japan have taken steps in the field of neologism to preserve and guarantee the existence of their languages (see Phillipson, 1992, p. 7; Fishman, 1998, 1999, p. 38). The French Professor Rene Etiemble declared war on the invasion of Anglo-Saxon words and phrases with his famous book, ParlezVous Franglais? Today, France recalcitrates using English in mass media, technology and diplomatic affairs. Germans are alarmed with the publications increasingly made in English (Fishman, 1998, 1999,

2 Gökçeli, Y. K. (2008, February 28) Kültür ve Sanat Büyük Ödülleri Konuşması. https://www.youtube.com/watch?v=jbXoRiLU4bg

Adres

RumeliDE Dil ve Edebiyat Araştırmaları Dergisi Osmanağa Mahallesi, Mürver Çiçeği Sokak, No:14/8 Kadıköy - İSTANBUL / TÜRKIYE 34714 e-posta: editor@rumelide.com tel: +90 $5057958124,+90216773$ o 616

Address

RumeliDE Journal of Language and Literature Studies

Osmanağa Mahallesi, Mürver Çiçeği Sokak, No:14/8

Kadıköy - ISTANBUL / TURKEY 34714

e-mail: editor@rumelide.com,

phone: +90 $5057958124,+90216773$ o 616 
p. 38). Tsuda deplores the penetration of English into every segment of life, and he finds the rise of using English in Japan in varying fields lead to Anglomania among the Japanese (1998, p. 227).

Kenyan writer and a dedicated language critic, Ngugi wa Thiong'o (2009) severely criticized the common use of English in his country blaming it for causing the loss of memory and cultural heritage for the sake of Europhonism. Therefore, he switched to Gikuyu for his literary creativity. In the same vein, being handled both as a political issue and discussed at the very core of the arguments regarding national identity and cohesiveness in Malaysia, English has aroused debates particularly among nationalist Malaysian groups who are convinced about the unifying function of Bahasa (Campbell, 2018, p. 208).

Mühlhäusler (2002) deplored the decrease of linguistic diversity in Pacific due to the impact of linguistic imperialism (p. 309). Urging that a large-scale linguistic genocide happens across the world, Skutnabb (2001) called attention to the death of languages resulting in the decline of the linguistic, cultural and spiritual diversities of the world (p. 206-7). However, it is Robert Phillipson, who has conceptualized the worries over and reactions against the expansion of English within the frame of linguistic imperialism, in his the very same name book, Linguistic Imperialism.

Several Turkish scholars focused on learning and teaching of English, and its offshoot influences in Turkey from wide range of perspectives. Oktay Sinanoğlu (2000) placed a great emphasis on the dangers of making English the language of instruction at schools, especially in higher education. Drawing upon the history of Turks and foreign effects on its culture and language, Akdeniz (1997) argued that the increasing impacts of Western languages, but not particularly referring to English, cause a kind of cultural degeneration in Turkey. Kabaklı $(1971,2009)$ drew attention on the rise of English language and culture through Americanization in Turkish streets, stages and media (p. 205). Defne Erdem presented some language problems like pronunciation in Turkish emanating from English loan words and related it with nationalist worries. Yet, the impact of English on Turkish language and people especially the young have not been handled and extensively examined from the perspective of linguistic imperialism put forward by Phillipson. This article discusses/critiques the hegemonic influence of English on Turkish and Turkish people utilizing the concept of linguistic imperialism. To this end, first the changes observed in Turkish linguistic landscape are critiqued, then a few examples showing the young's attitude toward English has been evaluated in reference to English expansion. Finally, to demonstrate the change and erosion in Turkish as a result of the increasing loanwords from English, a wide range of examples categorized under Turkilish are examined and evaluated in the relevant context.

\section{How English linguistic imperialism applies to Turkey and Turkish}

Linguistic imperialism, which can be briefly described as the dominance of a language over other languages replacing or displacing them and thus establishing its own superiority in all fields of life, constitutes the focal point of this study. This concept was excogitated by Phillipson in his Linguistic Imperialism (1992) as a particular theory to analyse the relationship between the dominant and dominated languages. Phillipson (1992) concentrated on English linguistic imperialism in many of his works that he defined as "the dominance of English maintained by the establishment and continuous reconstitution of structural and cultural inequalities between English and other languages" (p. 47). He specifies structural inequality in terms of "material properties (for example, institutions, financial allocations)" and the cultural inequality as "immaterial or ideological properties (for example, attitudes, pedagogic principles)" (1992, p. 47). More simplistically, based on these inequalities, "Linguistic imperialism builds on the assumption that one language is preferable to others and its dominance is

\footnotetext{
Adres | Address

RumeliDE Dil ve Edebiyat Araştırmaları Dergisi $\quad$ RumeliDE Journal of Language and Literature Studies Osmanağa Mahallesi, Mürver Çiçeği Sokak, No:14/8 $\quad$ Osmanağa Mahallesi, Mürver Çiçeği Sokak, No:14/8 Kadıköy - ISTANBUL / TURKIYE 34714 Kadıköy - ISTANBUL / TURKEY 34714 e-posta: editor@rumelide.com e-mail: editor@rumelide.com, tel: +90 505 7958124, +90 2167730616 phone: +90 505 7958124, +90 2167730616
} 
structurally entrenched through more resources to it" (Phillipson, 2003, p. 162). Phillipson's theoretical approach was opposed by a good few of other linguists like David Crystal, who argued that English became global thanks to its fortune of being in the right place at the right time (2012, p. 78), De Swaan, and Bloommaert, who judged this expansion in neutral spheres. In this sense, as Coluzzi rightly classified there are two main schools of thought: the pessimists who criticize expansion of English finding it imperial, and optimists who find that expansion natural and even useful (2012, p. 118). Although this paper does not intend to adopt an entirely optimist or pessimist view, since the literary review, context and facts of Turkey apply more to that of 'pessimist' counted paradigm of linguistic imperialism, the latter thought has been utilized in order to critique the instance of English in Turkey.

In the context of Turkey, even if the dominant language is Turkish, English is open to dominate all other eastern (like Arabic and Persian) and western languages (such as French and German), and emerge as an outstanding foreign language. Phillipson's fixation of inequality in languages can be clearly seen in Turkey's language policies particularly followed after 1950s when English, stepping forth among other languages taught at schools, captured the top as a foreign language. The following table shows the order of European languages taught at Turkish schools according to periods.

Table 1. Periodical precedence of European Languages in Turkey

$\begin{array}{llll}\text { Order of Priority } & \mathbf{1 9 2 3 - 1 9 5 0} & \mathbf{1 9 5 0 - 1 9 8 0} & \mathbf{1 9 8 0} \text { an } \\ \mathbf{1} & \text { French } & \text { English } & \text { English } \\ 2 & \text { English } & \text { French } & \text { German } \\ 3 & \text { German } & \text { German } & \text { French }\end{array}$

(Oral, 2010, p. 63)

English has been given priority since 1950 a and getting most of state funds allocated for language learning. In 2019, registering at private language courses, learners spent 300 million TL to learn English (Karaaslan, 2019), adding this state expenditure, English gets the lion's share in education budget on its own.

Among varying reasons for the changes in this priority, with respect to its propriety to author's conceptual analysis, comes first the establishment of close relations with the US in foreign politics particularly after becoming a NATO member in 1952. As Rothkopf emphasized, it has been one of the principal goals of the US state policy to promote English across the whole world,

\begin{abstract}
It is in the economic and political interest of the United States to ensure that if the world is moving toward a common language, it be English; that if the world is moving toward common telecommunications, safety, and quality standards, they be American; and that if common values are being developed, they be values with which Americans are comfortable. These are not idle aspirations. English is linking the world. By David Rothkopf (as cited in Phillipson, 2007, p. 381).
\end{abstract}

Thus, Turkey-US convergence can be said to have induced the commencement of English learning campaign in Turkey extending from state schools that start English instruction with $2^{\text {nd }}$ graders to private courses that start it with $1^{\text {st }}$ graders at primary education, which has made English unequivocally "a must learn" language.

The pivotal role of the US in promoting English at a global scale is closely linked to globalization process that it heads in world trade, politics and education. Globalizers, as Mandal suggests "actively promote English" (cited in Coluzzi, 2012, p. 120). Phillipson finds the supreme influence of US in the ongoing

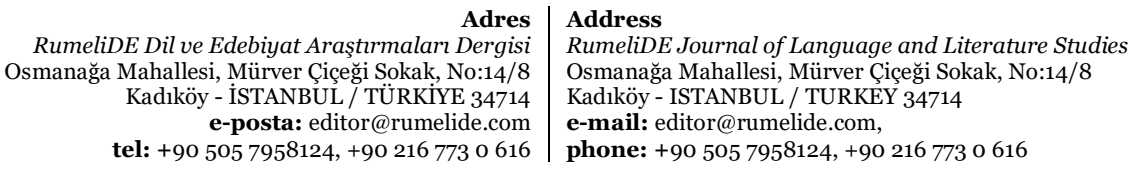


process of English hegemony to be more powerful than the impositions of British colonialism (as cited in Harper, 2011, p. 517). Unlike British colonial language executions, the US maintains a subtle way of promoting English which is succinctly stated by Phillipson as:

Instead, the United States often exerts its influence by maintaining hegemonic power structures that allow for a more subtle type of dominance that relies on both top-down institutional pressures and bottom-up choices by individuals who rationally wish to accrue the benefits that come with English fluency (as cited in Harper, 2011, p. 517).

In Parallel with Phillipson, Coluzzi's calims that "globalisation, in fact, is normally hierarchical in the sense that more prestigious languages and cultures tend to take over less prestigious languages and cultures in a top-down process". (2012, p. 119). Besides, the article by Scott and Venegas broadly critiques linguistic hegemony in the US today and concludes that "English-only policies" and "graduate mandates" serve consolidation of English hegemony whereas ignoring students' capabilities, and opportunities in other languages (2017, pp. 19-21). Our table above demonstrates the top-down institutional and official imposition of English as mandate language at schools also works in Turkey, which is a case that would later trigger a bottom-up individual choices of both learning English and using it while naming their workplaces, all contributing to the establishment of English hegemony in Turkey.

Throughout Turkey, using English for billboard ads, brands, products, cafes, hospitals, shops, stores, malls and other workplaces all of which are placed in Landry and Bourhis's 'linguistic landscape' has unprecedentedly increased in recent decades, which can be seen as a factor that accelerates language creolization and cultural alienation. In their comprehensive study on foreign name brands in Turkey, Bardakçı and Akıncı (2014) found out that the rate of using of foreign words, most of which are English for brands is $64.41 \%$ among about 4,000 brands selected from 15 categories, and this rate is the highest in cosmetics with $96.54 \%$ (p. 2). Yaman's case study of Samsun province of Turkey puts forward a similar portrait with naming workplaces in Samsun in which English is the most preferred language for naming workplaces after Turkish, and thereby the most effective language that both inquinates and creolizes Turkish (2016, p. 222). Furthermore, there is a growing inclination for generating foreign name brands mainly because they are supposed to have more positive connotations such as being more reliable and of higher quality than the local ones. This supposition, in fact, both emanates from the belief that Turkish falls short of reaching their products, brands and workplaces to success, and Coluzzi's theory that "more prestigious languages and cultures suppress the less ones" (2012, p. 119), whereby English is being considered more prestigious and posher than Turkish. As a consequence, people speaking Turkish may be said to be slowly but surely stepping toward alienation from their national language.

By the same token, hotel names are extensively in foreign languages especially in English or a mixture of foreign and Turkish phrases. Dr. Aydoğan (2012) demonstrated that among the names of 318 hotels chosen across Turkey and Northern Cyprus, only 30 are completely in Turkish (p. 24). Day by day, Turkish brand and place names are giving way to English. All of these developments are happening not because of externally American or British impositions, but rather, they seem endearing to many Turkish people, which is a case that justifies Phillipson's assumption concerning the self-endearing method of the USA building a hegemonic power as cited above. Therefore, Turkish streets and cities are turning into the reflection of half English and half Turkish combinations, which precariously influences and threatens the future of Turkish acquiescing to alienation in language and culture. In other words, Turkey is rapidly heading towards linguistic and cultural homogeneity with the native English-speaking world. Tripathi (2014) evaluates this kind of step as an "exercise of imperialism" (p. 320) which fits in the category of linguistic imperialism under discussion.

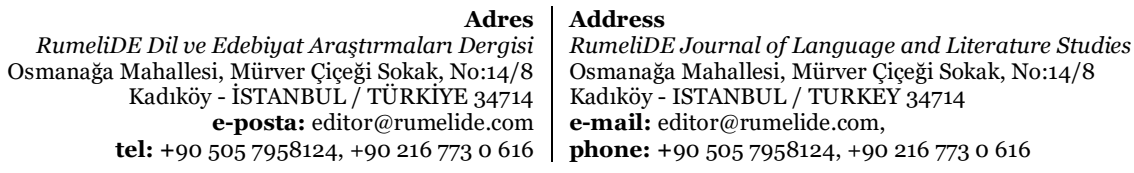


Just like numerous shops, restaurants and firms, countless Turkish magazines in diverse sectors imbibed English to an extent of emerging with English names; Auto World, Bast Home, Turkish Student and Mall Report epitomize this tendency. The dailies and TVs also increasingly began to use English terms in their press and broadcasts. First channel names became English such as Show, Star and Flash and then the programs on TVs adopted English names like Top Secret, Pop Stop, Top On, First Class and Magazin Forever (Hepçilingirler, 2010, p. 44). This willing acceptance, however, plays a key role in subjecting the country to a mono-language and monoculture as pointed out by Niu Qiang and Martin Wolff for a similar situation in China (2005, p. 56). Having intensively researched this issue of using English phrases in media, Şahin urges that:

\begin{abstract}
Although the Turkish language has equivalents for some of the loanwords, many people including journalists and news reporters who have to be careful about the use of language, who are effective on the people and who lead the public opinion use English words (2005, p. iv).
\end{abstract}

The rise of foreign words in media seriously signals that they will play a major part in the development of Turkish linguistic standards considering the fact that media plays a substantial role in the development of linguistic standards in a country as pointed out by Dor (2004, p. 113). To put in another way, English apparently seems to be one of the indispensable elements while determining the standards of Turkish

Phillipson paid particular attention to the colonial and neo-colonial and Centre-Periphery characteristic of linguistic imperialism. He formulated it in the axis of colonizer-colonized relationship which encompasses the emergence of the elite of a society:

\begin{abstract}
In the early colonial phase of imperialism, the elites in the Periphery consisted of the colonizers themselves, whether settlers or administrators. In present-day neo-colonialism, the elites are to a large extent indigenous, but most of them have strong links with the Centre. . . An increased linguistic penetration of the Periphery is essential for completing the move away from crude means, the sticks of colonial times, and even the more discreet means of the neo-colonialist phase of asymmetrical bargaining, to neo-neo-colonialist control by means of ideas (1992, pp. 52-53).
\end{abstract}

In parallel with Phillipson, Canagarajah (1999) defined the Center as "technologically advanced communities of the West where English is the native language" which is synonymous with the concept of 'Inner Circle' Kachru (1992) used for English native speaking countries, and the Periphery for the communities in which English is the postcolonial legacy such as in India, Barbados and Nigeria (p. 4). In this paper, the Periphery corresponds to Kachru's 'Outer Circle' that includes ex-colonies of Britain, and 'Expanding Circle' which refers to those countries like Brazil and Turkey where English is learnt as a foreign language. As mid-20 $0^{\text {th }}$ century, Turkey was encouraged under the presidency of Özal to be like a miniature America in every aspect, an attempt that made an overwhelming impression in Turkish culture and language (Sarı, 2008, p. 37). Considering the prestigious position of the US in higher education, political, economic and military arenas, Özal may have wished to create a small but developed country in the Middle East like the US, and his wish can also be interpreted as the divulgence of the comprehension at least by some in Turkey of the Anglo-American world as the Centre. Since his time, both political, military and economic affairs with the US have been maintained albeit with interval mutual resentments. As a result, today, English has become as aforementioned, become the indispensable foreign language and England and the US are among the most preferred countries by Turkish youth both for education and living (Keşfetsek, 2020), which demonstrates that linguistic penetration into peripheries also reinforce the perception that Anglo-American countries are the Center of the world.

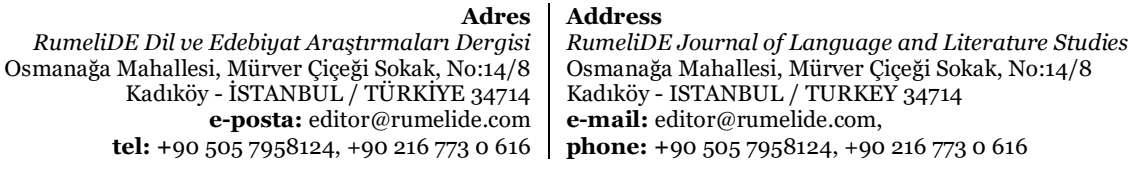

RumeliDE Journal of Language and Literature Studies

Osmanağa Mahallesi, Mürver Çiçeği Sokak, No:14/8

Kadıköy - ISTANBUL / TURKEY 34714

e-mail: editor@rumelide.com

phone: +90 505 7958124, +90 2167730616 
The tendency of learning English in Turkey does not seem to be innocuous as it appears since it has already moved beyond just being a means to an end, but rather, turned into a purpose, or even, an ultimate goal. In accordance with this, many students prefer, or, are directed at schools particularly at universities to learn English ignoring their other abilities and areas of interests. Thus, English has become an indispensable and unquestionable part of Turkish youth's personal identity. The survey conducted by British Council put that Turkish youth staunchly believe in learning English to be successful and some even conceive it as their ultimate goal as openly expressed by a young woman; "Now everything leads up to English. That's to say, it stands as an obstacle before me to reach opportunities (Age 27)" (Ateş et. al., 2017, p. 44). This woman is, at the same time frustrated because of not being able to learn English to find a job or evaluate other opportunities, which directly means English proficiency, whilst offering opportunities to young on the one hand, on the other hand prevents them from reaching their goals and needed facilities. Another respondent woman aged 23 says; "I would like to go abroad in order to improve my English. My goal is English now" (Ateş et. al., 2017, p. 44). She both manifests that English has become an ultimate goal rather than being a medium to be attained and the difficulty of learning English at home which dispatches her to travel abroad. The poll conducted by British Council supports this young woman, exhibiting that only $7 \%$ of the young can reach advanced level English whilst the rest dwells at intermediate and elementary levels (Özen et al., 2014, p. 93). Considering the economic status of the young and July 2020 unemployment rate of 25, 9\% among them (15-24 ages) according to the data of Turkish Statistical Institute (cited in Gazete Karınca, 2020), her second preference of going abroad for English education seems not an easy-access choice. In addition, the same research by British Council holds that most Turkish youth want to learn German, Spanish, Russian and Arabic after English (Özen et al., 2014, p. 95), from which can it deduced that those young unsuccessful in English can be directed or enabled opportunities to learn another language/s in line with their preferences. Accordingly, from these answers and statistics, it transpires that Turkish youth particularly those coming from low economic section of the community will continue to suffer from unemployment because their English is not sufficient and be left to a desperate situation for not realizing their dreams and goals. Put it differently, English-only policies dictated by Anglo-American world as Phillipson underlined, or established English linguistic hegemony while pleasing some lucky part of the society, drag a considerable number of youth to a formidable despondency.

Some top Turkish universities such as METU, Bosphorus and Bilkent have already been using English as a medium of instruction of which Sinanoğlu heartily complained in his Bye-Bye Türkçe (2000). More and more universities are heading toward Englishizing their syllabuses and programs; İstanbul University, Marmara University, Anadolu University, Yıldız Technical University and many others have both $100 \%$ and 30\% English programs. In rise of this rate among many other factors, are also found Bologna process and EU student exchange programs like Erasmus and Socrates that require English knowledge first of all. Phillipson observes that "Bologna process that seeks to integrate the research and education systems of 45 European countries into a single and unified area" for the sake of internationalization (2008, p. 31). This internationalization, however, for him means English-medium education rather than conferring on multilingualism (Phillipson, 2008, p. 31). Universities are indeed the institutions where knowledge is produced by academics and young scholars for both the world scholarship and national benefits and practices. If all the knowledge is produced in English at Turkish universities, who will be able to understand and make use of it but the advanced English knowers? Would not then be formed a deep gap between the English using academics and Turkish speaking public? In the interview he gave to Yüzgenç, Professor M. F. Andl, after acknowledging foreign languages should be learnt, objects like Sinanoğlu to education in a foreign language (here English implied) that he asserts helps colonization of society; allowing the nation access to knowledge in that language but

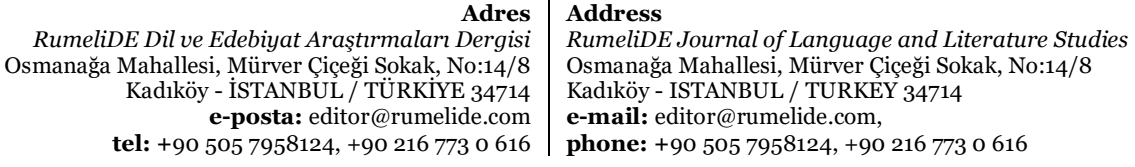


brings in the long run together cultural and identical alienation from Turkish language and cultural roots (Yüzgenç, 2016). Furthermore, considering the rate of Turkish youth well versed in English (see Özen et al., 2014, p.95), it does not seem a trustworthy introduction of courses and knowledge will be realized in English. Therefore, English-medium education can be claimed to some extent, if not wholly, serves consolidation of English hegemony in Turkish institutions rather than being used as an effective means of nurturing knowledge and disseminating it within the country.

Indeed, whether English should be optimally learned or not is interrogated neither in Europe (Phillipson, 2009, p. 97) nor in Turkey. Accordingly, more and more students and people from various jobs and age groups engage in trying to learn English whether their profession and position requires it or not. By virtue of this tendency, Akdeniz (1997) asserts "The highly valuable money, labour, mind and brain power which are required to be used to serve the very important needs of developing countries and time are wasted in the consumption of foreign language and culture" (pp. 310-311). This consumerism is today among the leading agents counted by Phillipson that gains English a progressively more imperial status (2015). In the same vein, Özdemir (2006) reports that "In our country, foreign language, rather than being a medium that we can utilize in order to reach contemporary sources of information, is taught because it is thought that everybody must learn it. Most people even are not aware of why they learn a foreign language" (p. 30). Because of this lack of awareness, the real danger as ElQassaby (2015) opines, lies in being re-shaped by this language in terms of culture and identity (p. 62). In support of El-Qassaby, Waseema and Asadullah (2013) claim that "The target language influences thoughts and world views and forces the non-native learner to think in certain established ways" (p. 802).

\section{Linguistic borrowing and emergence of Turkilish}

To the knowledge of all, linguistic borrowings and exchanges have always been in the history of human beings, and these mutual exchanges have created the languages we are using today. However, the $21^{\text {st }}$ century world is face to face a monolingual loan or transfer; English as the language that affects other languages and cultures most. Phillipson briefly accounts this case putting forward, "linguistic imperialism presupposes an overarching structure of asymmetrical, unequal exchange, where language dominance dovetails the economic, political and other types of dominance" (2009, p. 2). To account for this kind of import-export relationship, Cooke uses the metaphor of the Trojan horse to describe the way in which English may be welcomed at first yet later it causes concerns regarding the suppression of the native languages and local cultures (as cited in Galloway \& Rose, 2015, p. 59). While implementing language instruction and trying to catch up with Western technology, economic welfare and science, importing more and more words due to the inequalities in trade, science and other fields has become inevitable for Turkish. Myriads of English words flow into Turkish via technology, entertainment, social media, science and education. What this study complains is not borrowing or appropriating words from English or other languages, but the linguistic inquination of Turkish language emerging through Turkilish phrases and concomitant cultural degeneration.

In Turkey, more vital than the use of loan words, is the increasing propensity for using English and Turkish phrases together in a style called either "Plaza Turkish", referring to the language used by white collar workers at Plazas (Efe, 2019, pp. 103-4), or Turkilish, which is used by all people who mishmash Turkish and English independent of business concerns. In fact, that English has a global presence has given birth to the emergence of several hybrid styles of English such as Konglish (English in South Korea), Manglish (Malay and English), Hinglish (Hindi and English) Singlish (Singaporean English)

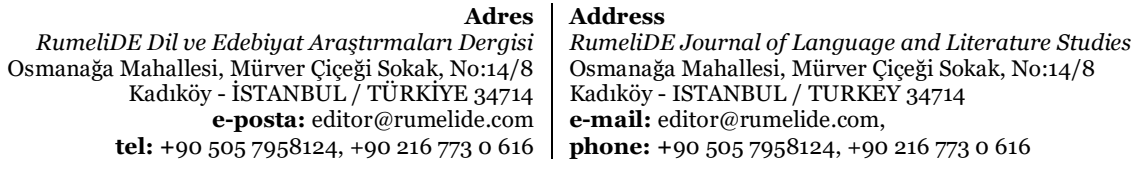


and the notion of Globish. It does not seem that this trend of hybridization will take a pause as long as the English linguistic imperialism endures. The most common ways of making a Turkilish colloquial idiom which is especially in vogue among the young, include the verbs "to be" (olmak), and "to do" (etmek) as seen in Hepçilingirler's Turkilish sentences exemplify:

"Overload oldum (I was overloaded). Bu case'i handle edebiliyor olmalnyız (We must be handling this case). Sizinle hemen bir meeting set edelim (Let's set a meeting immediately). Üstelik kurumsal assetlerimizi maximize edecek (Furthermore, it will maximize our institutional assets). Mailleri de forward ediyorum (I am also forwarding emails)" (2016).

In her comprehensive book on foreign words and misuses in Turkish, Hepçilingirler continues to bring examples for Turkilish uses as,

“Haydi bakalım playliyoruz” (Let’s play); “Türkiye’de talkamayan insanlarla talkshow yaptırldığ sürece..." (As long as people who can't talk have been assigned to throw talkshow...) (p. 45); "Bunu correct bulmadım" (I didn't find it correct) (p. 211), "Saçlar artık perfect" (Now, hair is perfect) (2010, p. 219).

In parallel with Hepçilingirler, Diker also presents a sample dialogue in Turkilish;

“Selam nasllsin?” (Hi, How are you?)

“İyilik valla, busy busy. Ya sen?” (I’m OK, busy busy. How about you?)

“Fena değil, no complaint. (Not bad, no complaint)

(Diker, 2016).

The Turkilish examples brought by both Hepçilingirler and Diker make it evident that the rules of Turkish grammar and linguistic structure have already been ignored and cast aside in consequence of the unremitting invasion of English terms. In order to understand these excerpts, one is required to have the knowledge of both English and Turkish, which is underlined by Kubota and Word as: "English is replacing many lexical items in other languages, reinforcing a situation in which knowledge of English is required even for basic literacy in these languages (2000, pp. 82-83). Given that such kinds of phrases are popular, the dose of linguistic degeneration in the form of Turkilish seems rather alarming, a fact that represents English linguistic threat to Turkish language.

Intense infiltration of English into Turkish results in the attrition of the native language and accordingly its own product, Turkish culture. The more Turkilish is used in speaking and writing, the more Turkish depletes, which in time leads to the marginalization and even inferiorization of the language itself, and the culture it preserves. As a result, the future of correct Turkish seems perturbative, and an appropriate transfer of cultural and historical heritage to the future generations via language is endangered (Tosun, 2005, p. 136). Henceforth, depending upon the increase of Turkilish usages, fostering and maintaining creativity in Turkish language together with national heritage is impeded. Concerning this, Sapir (1970, p. 193) pointed out that "The extent to which the vocabulary of a language filters into another language plays a role in the development and spread of cultural ideas." If the speakers of a language remain incapable of generating ideas and thoughts by utilizing their language appropriately, then the weight of the civilization that language is required to bear as Fanon enounced, $(1952,2008$, p. 2) faces the danger of being dominated by the puissant one and even gradual disappearance. Even if it is too early to mention

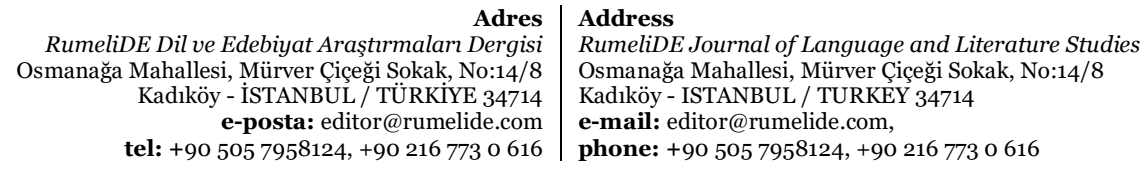


in Turkey such kind of a disappearance, it is obvious from Turkilish usages that Turkish of future will be different from Turkish of present not to mention of past.

This paper does not object to getting loanwords from English or other languages, all languages borrow and lend lexical items, but grumbles lack of any kind of institutional, official or social supervision mechanism or state policy that displays sensitivity on correct use of Turkish in media, TV and dailies. Now that there is Turkish Language Association, as an association devoted to Turkish, and 2017 was declared by the President Erdoğan as the Year of Turkish, why have they not become effective or registered success? As a consequence, it is needed to ask "Is it too late to act against linguistic imperialism or is it impossible to resist English hegemony?" Can't we learn English very well without damaging Turkish language, culture and linguistic landscape? Are we doomed to compromise Turkish while learning English? Inescapably arise such questions that we have to discuss both at academic and political level. Although it is hard to find an answer or multiple answers in the short haul, in order to avert further linguistic, and landscape equinations which are immanently related with each other, it is beyond doubt we have to generate effective educational politics, and raise consciousness at communal level not to mention in the media. Phillipson's suggestion against linguistic imperialism is language ecology that pays regards to diversity of languages rather than prioritizing one or few languages (cited in Gayton, 2016, p. 233). One of his latest articles, having found it difficult to combat English linguistic imperialism, urges "The context of the major expansion of English has been as an integral constituent of global finance capital and commerce. English learning is now prominent in school education in many parts of the world...” (2019, p. 28). In this statement, Phillipson points to global finance and commerce as well as US and UK English policies in education as the biggest actors catering to establishment of English hegemony. So, every national attempt like declaration of Turkish Year in 2017 in Turkey that does not have an immense financial and international support against English linguistic imperialism seems to remain ineffective. One possible suggestion is; just like nations form political and economic unions to observe their political and economic interests, Turkey and its neighbouring countries - since it is challenging to do it worldwide - can attempt to form a cultural union at regional level in order to struggle against English linguistic hegemony. Such that, it can encourage at home learning the languages of neighbouring countries both to increase commercial, political and cultural cooperation, and can demand its neighbours to include Turkish as part of their syllabi. Execution of such a project, according to my humble deduction, can serve both reinforcement and expansion of Turkish in the region, and preservation of the linguistic and cultural identity of the nations in the region as well as economic development of Turkey and its neighbours.

In summary, the inevitable consequence of English admiration and random uses is the decrease of productivity in Turkish and cultural erosion. Paralleling with this, crops up the crisis of accurate and intact transmission of the mother tongue to the next generation since the language has already been muddied by the outer impacts and issuing improper uses, whereas Vuolab (2000) advocated that "By passing on our language, the mother tongue, to the next generation, we ourselves guarantee that life itself will continue into the future" (p. 13). It is widely observed both in the Turkilish uses, and equination in linguistic landscape that, instead of coming up with new Turkish origin words, phrases borrowed from English are used either by their pronunciation or written form. Furthermore, since the world around us is analyzed, structured, shaped and assessed by the language we use, the more English words come into our life, the more our world becomes estranged from its original roots, and resemble to the dominant language and culture. In this regard, the world is heading rapidly toward a linguistic and cultural synchronization stressed by Coluzzi (2012, p. 118)

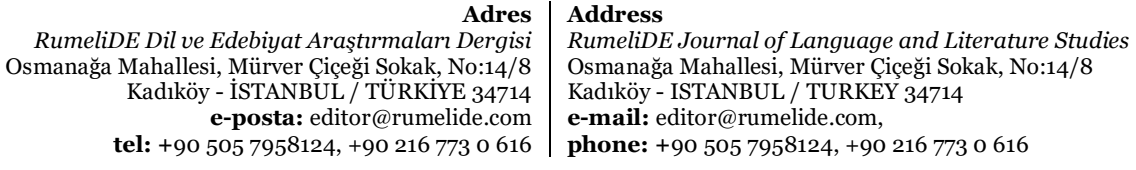

RumeliDE Dil ve Edebiyat Araştırmaları Dergisi tel: +90 505 7958124, +90 2167730616

phone: +90 505 7958124, +90 2167730616 


\section{Conclusion}

The British Empire has given way to English linguistic imperialism, and English has been precipitously diffusing into other languages by enclaving them via diverse ways without being much called into question. At this juncture, it is necessary to comprehend that this invasion has political, ideological, economic and cultural implications, and thus confront the imperialistic and assimilative effects of English while learning and using it. With regards to university education and future economic worries in particular, English-only or English as sine qua non image seated in Turkey, like elsewhere, carries fire in hand and water in the other; while benefitting those can learn it fluently, causes frustration among the majority.

Prima facie, it may not seem alarming to deem that Turkish language is threatened by erosion or replacement by English. However, the facts that Turkish media, newspapers, TVs, and even public dialogues are all replete with non-Turkish words coming mainly from English, and Turkilish way of speech and writing is gaining more root and prevalence amidst the youth proves that the Turkish language is getting contaminated, and thereby dynamics characterizing cultural assets are becoming assimilated.

To rid itself of the deleterious effect of English hegemony, accurate use of Turkish should be encouraged particularly by the relevant state ministries and offices, regularly inspecting and warning media and TV organs. At this point, it is incumbent both upon the Turkish Language Association to inspect the permeating phrases and immediately bring proper correspondents and new derivation forms, and higher education institutions to revise their language teaching program in line with the country goals and needs.

At a national scale, this paper does not directly suggest to abandon learning and using English for diplomatic, commercial, academic, educational, professional or other goals but on the contrary, English needs to be learnt and used accurately and consciously so as not to allow linguistic hegemony of English. Putting it differently, it is necessary to learn it proficiently both in order to resist the cultural hegemony it imposes, and preclude its intensive influence as Bourdieu emphasized (cited in Phillipson, 2015). Yet, foreign language learning ought not to allow the distortion of Turkish, or be solely confined to English, which is obligatory from the $2^{\text {nd }}$ grade of primary school to university. Some other languages whether Western or Eastern (languages of the Middle Eastern countries in particular), should be offered as options and means of opportunities to students particularly for those who are incompetent in English, as an effective way of precluding language discrimination. In this regard, I have to give Turkish Ministry of Education credit for including Arabic as an elective foreign language both at secondary and high schools (MEB, 2016, 2017, pp. 6-13), which can be considered as a significant step promising hope for Turkish youth especially for those who fail or dislike obligatory English courses.

\section{Bibliography}

Akdeniz, S. (1997). Kültür Sömürgeciliği. İstanbul: Marmara Üniversitesi İlahiyat Fakültesi.

Ateş, M. G. et al. (2017). Next Generation Türkiye: Gençlerin Sesini Dinlemek. Online Report.British Council.

Aydoğan, B. (2012). Türkçeye Giren Yabancı Sözcükler ve Otel Adları. Çukurova Üniversitesi Türkoloji Araştırma Merkezi, 468, 21-25.

Bardakçı, A. \& Akıncı, M. (2014). Türkiye'de Ürün Markalamada Yabancı Dil Kullanımı: Sebepler ve Sonuçlar. Tüketici ve Tüketim Araştırmaları Dergisi, 6(1), 1-26.

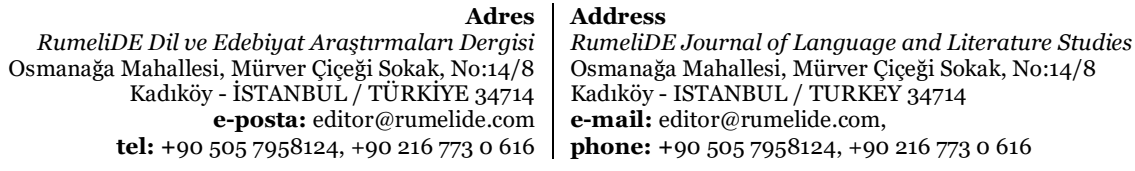


Campbell, J. (2018). English Language and an Inclusive Malaysia. 3L: The Southeast AsianJournal of English Language Studies, 24(3), 206 - 219. DOI: http://doi.org/10.17576/3L-2018-2403-15.

Canagarajah, A. S. (1999). Resisting Linguistic Imperialism in EnglishTeaching. Oxford: OxfordUniversity Press.

Coluzzi. P. (2012). Modernity and globalisation: is the presence of English and of cultural products in English a sign of linguistic and cultural imperialism? Results of a study conducted in Brunei Darussalam and Malaysia. Journal of Multilingual and Multicultural Development, 33(2), 117131, DOI: 10.1080/01434632.2011.640401

Crystal, D. (2012), English as a Global Language. New York: Cambridge University Press.

Diker, Y. (2016, February 2). Türkilizce. http://www.bizimanadolu.com/turkilizce/

Dor, D. (2004). From Englishization to Imposed Multilingualism: Globalization, the Internet, and the Political Economy of the Linguistic Code. Public Culture, 16.(1), 97-118.

Efe, K. (2019). Beyaz Yakalılar Dünyasının Dili: Plaza Türkçesi. ZfWT. 11(3), 103-126

El-qassaby, H. K. (2015). Linguistic Imperialism and Reshaping the World's New Identity: A RResearch Paper in Linguistics. International Journal of Language and Linguistics, 3(2), 61-68.

Fanon, F. (2008). Black Skin, White Masks. Trans. by Richard Philcox. New York: Grove Press.

Fishman, J. A. (1998/1999). The New Linguistic Order. Foreign Policy. 113, 26-32+34-40.

Galloway, N. \& Rose, H. (2015). Introducing Global Englishes. New York: Routledge.

Gayton, A. M. (2016). Perceptions About the Dominance of English as a Global Language: Impact on Foreign-Language Teachers' Professional Identity, Journal of Language, Identity \& Education, 15 (4), 230-244, DOI: 10.1080/15348458.2016.1194209

Gazete Karınca. (2020, October 12). İstihdam azalmasına ragmen işssizlik oranı değişmedi. Turkish Daily. https://gazetekarinca.com/2020/10/istihdam-azalmasinaragmenissizlikoranidegismedi/\#: :text=Bu\%20verilere\%20g\%C3\%B6re\%2C\%20T\%C3\%BCrkiy e\%2ogenelinde,y\%C3\%BCzde\%2013\%2C4't\%C3\%BC.

Harper, S. M. (2011). Counting the Costs of a Global Anglophonic Hegemony: Examining the Impact of U.S. Language Education Policy on Linguistic Minorities Worldwide, Indiana Journal of Global Legal Studies. 18(1), 515-538.

Hepçilingirler, F. (1997/2010). Türkçe “Off”. İstanbul: Everest Yayınları.

Hepçilingirler, F. (2016). Türkilizce’ye Doğru. Esinti Digital Edebiyat ve Sanat Dergisi. https://www.kasabadanesinti.com/turkilizceye- dogru-feyza-hepcilingirler/2879/

Kabaklı, A. (2009). Kültür Emperyalizmi. İstanbul: Türk Edebiyat Vakfı.

Kachru, B. (1982/1992). Ed. The Other Tongue: English Across Cultures. USA: University of Illinois.

Karaaslan, C. (2019, January 16). Öğrenciler İngilizce’ye 300 Milyon TL Harcadı. Sabah Daily. https://www.sabah.com.tr/egitim/2019/o1/16/ogrenciler-ingilizceye-30o-milyon-tl-harcadi

Keşfetsek. (2020, August 17). Ĕ̈itim İçin En Çok Tercih Edilen 5 Ülke. https://kesfetsek.com/yurtdisiegitim-gidilen-ulkeler/

Kubota, R. \& Ward, L. (2000). Exploring Linguistic Diversity through World Englishes, The English Journal 89(6), 80-86.

Master, P. (1998). Positive and Negative Aspects of the Dominance of English, TESOL Quarterly, 32(4), 716-727. MEB. (2016/2017). İlkokul, Ortaokul, İmam Hatip Ortaokulu ve Ortaöğretim Arapça Öğretim Programları. A Report by Ministry of Education. Ankara: MEB.

Mohanty, A. K. (2009). Multilingual Education: A Bridge Too Far? In Skutnabb-Kangas, Tove et al. (Eds) Social Justice Through Multilingual Education. Bristol, Buffalo \& Toronto: Cromwell Press Group.

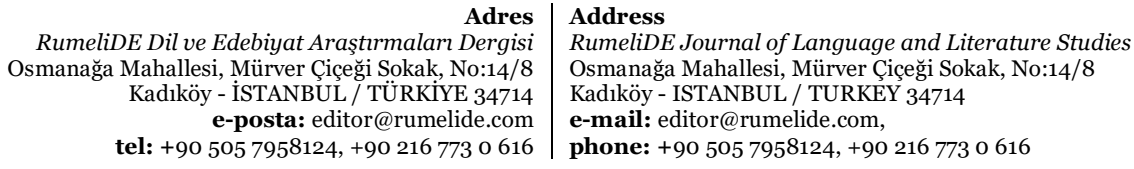


Mühlhäusler, P. (2002). Linguistic Ecology: Language Change and Linguistic Imperialism in the Pacific Region. London \& New York: Routledge.

Ngugi wa Thiong'o. (2009). Something Torn and New: An African Renaissance. New York: BasicCivitas Books.

Oral, Y. (2010). Türkiye'de Yabancı Dil Eğitimi Politikaları Bağlamında İngilizce: Eleştirel Bir Çalışma. Alternatif Ĕ̈itim e-Dergisi, 1, 59-68.

Özdemir, E. A. (2006). Türkiye’de İngilizce Öğreniminin Yaygınlaşmasının Nedenleri. Mersin Üniversitesi Eğitim Fakültesi Dergisi, 2(1), 28-35.

Özen, E. N. et al. (2014). Türkiye’deki Devlet Okullarında İngilizce Dilinin Öğretimine İlişkin Ulusal İhtiyaç Analizi. British Council TEPAV.

Phillipson, R. (1992). Linguistic Imperialism. Oxford: Oxford University Press.

Phillipson, R. (2009). Linguistic Imperialism Continued. New York \& London: Routledge.

Phillipson, R. (2007). Linguistic Imperialism: A Conspiracy, or a Conspiracy of Silence?, Language Policy, 6, 377-383.

Phillipson, R. (2003). English-Only Europe? Challenging Language Policy. London \& New York:Routledge.

Phillipson, R. (2009). The Tension Between Linguistic Diversity and Dominant English, In SkutnabbKangas, Tove et al. (Eds) Social Justice Through Multilingual Education.Bristol,Buffalo \& Toronto: Cromwell Press Group.

Phillipson, R. (2015). English as Threat or Opportunity in European Higher Education. In Dimova, Slobodanka et al. (Eds.) English-Medium Instruction in European Higher Education 3, Germany: Walter de Gruyter Inc.

Phillipson, R.. (2019). Language Challenges in Global and Regional Integration. Sustainable Multilingualism 12. pp. 14-35. DOI: https://doi.org/10.2478/sm-2018-0001

Phillipson, R.. (2008). The Linguistic Imperialism of Neoliberal Empire, Critical Inquiry in Language Studies, 5(1), 1-43, DOI: 10.1080/15427580701696886

Qiang, N. \& Wolff, M. (2005). Is EFL a Modern Trojan Horse?, English Today 84, 21(4), 55-60.

Şahin, U. (2005). Identifying the Words Entered Turkish From English. MA Thesis, Atatürk Üniversitesi, Erzurum.

Sapir, E. (1970). Language: An Introduction to the Study of Speech. London: Rupert Hart-Davis.

Sarı, M. (2008). Türkçenin Batı Dilleriyle İlişkisi. Ankara: TDK.

Scott, L. M. \& Venegas, E. M. (2017). Linguistic hegemony today: recommendations for eradicating language discrimination." Journal for Multicultural Education, 11.1, 19-30. DOI 10.1108/JME09-2015-0028

Sinanoğlu, O. (2000). Bye Bye Türkçe. Türkiye: Bilim + Gönül.

Skutnabb-Kangas. (2001). The Globalisation of (Educational) Language Rights, International Review of Education/Internationale Zeitschrift für Erziehungswissenschaft/Revue Internationale de l'Education, 47.3-4, 201-219.

Tripathi, K. (2014). Ma Patrie, C'Est la Langue Francaise'- LinguisticImperialism and Minority Language Rights in International Law. NUJS Law Rev. 7, 293.

Tsuda, Y. (1998). Critical Studies on the Dominance of English and the Implications for InternationalCommunication. Japan Review, 10, 219-236.

Tosun, C. (2005). Dil Zenginliği, Yozlaşma ve Türkçe”, Journal of Language and Linguistic Studies,1(2), 136-154.

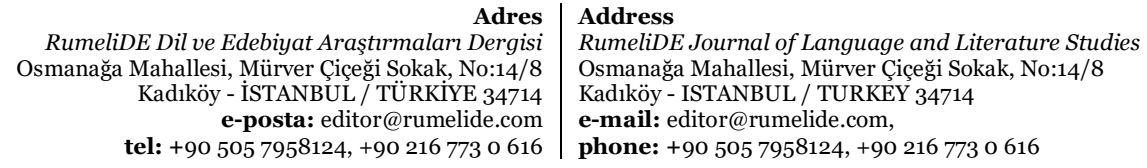

tel: +90 505 7958124, +90 2167730616

-mail: editor@rumelide.com,

phone: +90 $5057958124,+902167730616$ 
1080 / RumeliDE Journal of Language and Literature Studies 2021.24 (September)

A Critical approach to the use of English in Turkey in light of linguistic imperialism / A. Yiğit (pp. 1067-108o)

Vuolab, K. (2000). Such a Treasure of Knowledge for Human Survival, in R. Phillipson (Ed.), Rights to Language : Equity, Power, and Education (pp. 13-17). New Jersey: Lawrence Erlbaum Associates, Inc.

Waseema, F. \& Asadullah, S. (2013). Linguistic domination and critical language awareness. Procedia -Social and Behavioral Sciences, 70, 799 -820.

Yaman, İ. (2016). Türkçenin İngilizce Yoluyla Melezleşmesi: Samsun'daki İş Yeri ve Mekân Adları Örneği. Karadeniz Araştırmaları, 50, 217-229.

Yüzgenç, S. (2016). Yabancı Dille Eğitime Hayır, Yabancı Dil Eğitimine Evet. Genç, Online Interview. 114, https://gencdergisi.com/9705-yabanci-dille-egitime-hayir-yabanci-dil-egitimine-evet.html.

RumeliDE Dil ve Edebiyat Araştırmaları Dergisi Osmanağa Mahallesi, Mürver Çiçeği Sokak, No:14/8 Kadıköy - ÍSTANBUL / TÜRKIYE 34714 e-posta: editor@rumelide.com tel: +90 $5057958124,+902167730616$
Address

RumeliDE Journal of Language and Literature Studies Osmanağa Mahallesi, Mürver Çiçeği Sokak, No:14/8

Kadıköy - ISTANBUL / TURKEY 34714

e-mail: editor@rumelide.com,

phone: +90 505 7958124, +90 2167730616 